\title{
Modelling Modal Shift Preference of Freight Transport on Surabaya-Jakarta Corridor : A Preliminary Survey
}

\author{
Hartono Guntur $\mathrm{R}^{1^{*}}$, Indrasurya B Mochtar ${ }^{2}$, Hera Widyastuti ${ }^{3}$ \\ ${ }^{I}$ Doctoral Student of Postgraduate Program of Department of Civil Engineering, Faculty of Civil Engineering and \\ Planning, Institut Teknologi Sepuluh Nopember, \\ ${ }^{2}$ Lecturer, Department of Civil Engineering, Faculty of Civil Engineering and Planning, \\ Institut Teknologi Sepuluh Nopember, \\ ${ }^{3}$ Lecturer, Department of Civil Engineering, Faculty of Civil Engineering and Planning, \\ Institut Teknologi Sepuluh Nopember, \\ *Corresponding author: gunturhartono@yahoo.com
}

\begin{abstract}
The market share of freight transport which is dominated by road transport and accompanied by unbalanced of infrastructure's growth and freight demand has created various negative impacts on existing transportation system. The shift of freight transport from road to rail and sea is expected to reduce those impacts. Research on the behavior of freight mode choice and the extent to which the user is willing to trade off the attribute change needs to be done so that the amount of modal shift will be known. The main objective of the study was to produce a model of mode choice based on preference surveys among forwarders, as well as to provide inputs for policy improvement and or improvement of freight transportation services. One of the surveys to be conducted is the revealed preference (RP) survey. The important stage before the RP survey is to conduct a preliminary survey. This stage aims to determine the important trends related to the choice of modes by the forwarder and test the response rate of respondents. The survey is also useful for assessing the credibility of the data instrument, identifying potential errors in the data instrument, and determining non-conformities in survey management before the actual survey. Data collection was done by sending questionnaires. The structure of the questionnaire consists of questions about characteristics of : shipment, travel, and modes. The results of survey showed relatively low response rate because it was only 8 respondents who were willing to answer the questionnaire. This indicates that the questionnaire needs to be combined with other methods, such as: face to face interviews and or focus groups. The results of the preliminary survey show that the main factors for the choice of existing modes are: shipment costs, loss/damage, and time travel. The implementation of the next stage survey should consider that each company has more than one shipping commodity so it is necessary to group questions and analysis based on each commodity.
\end{abstract}

Keywords: freight mode choice, forwarder, revealed preference (RP)

\section{INTRODUCTION}

\section{A. Background}

Java Island, especially Java North Coast corridor, and more specifically two major cities of destination of freight transportation, namely: Jakarta and Surabaya, have an important role in the development of Pendulum Nusantara with Belawan, Makasar and Sorong. While from the side of the national economic corridor, Java Island is an island that is directed to the island of National Industrial and Service Entrepreneurs. The city of Jakarta and Surabaya themselves are the city of Mega Economic Center in the scheme of national economic corridors. The Jakarta-Surabaya corridor is also a strategic corridor of freight transport with a volume of goods 40-50 million tons per year. Tanjung Priok Jakarta and Tanjung Perak Surabaya as strategic ports and the first and second largest ports in Indonesia, have a very significant role in supporting the national logistics system [1]. So the Surabaya-Jakarta corridor is very relevant as the focus of research.

Based on data in 2013, the share of freight transport using sea mode is $7.07 \%$, rail; $0.63 \%$, and road; $91.25 \%$. While the rest, transported other modes of transportation [1]. Approximately 51\% movement in the island of Java is also indicated to be dominated by the road. More specifically in the north coast line of Java (Pantura), the current mobilization of cargo from Surabaya to Jakarta and vice versa served by 3 modes of transportation, namely: trucks, trains, and ships. However, the majority of overland cargo transport is served by trucks [2]. The use of river, lake and ferry modes (ASDP) as well as sea/marine modes for inter-provincial freight transport in Java Island with provinces outside Java indicate a small percentage. Likewise, the use of air mode as a freight transport in Java is relatively small percentage of the use of railways and road [3]. As for export purposes, most exporters and forwarders in Java Island prefer container trucks for the shipment of exported cargo through three major ports (Tanjung Priok, Tanjung Perak and Tanjung Emas). Meanwhile, the use of container trains is only about $4 \%$ of the total shipment of goods from and to the three ports [4].

The market share of freight transport dominated by the road mode and accompanied by the growth of facilities and cargoes that are not offset by the growth of infrastructure has caused negative impacts on the freight transport system. On the other hand, non-road mode both aspects of infrastructure and facilities have the potential to be developed together with the road mode as a mode 
of transportation of goods. This is evident from the strategic plans of stakeholders, both policy makers and freight transport operators. A proportional share of the freight market is expected to maximize the advantages of one mode and minimize other modes of deficiencies so as to minimize negative impacts.

\section{B. Aims and Objectives}

The movement of freight to non-road mode will depend on the mode choice behavior. Research on the behavior of mode choice and the extent to which the user is willing to trade off the change of attribute modes needs to be done so that the amount of modal shift will be known. Therefore, the main problem of this research is: how to improve the movement of freight mode from road to sea and rail mode? What are the scenarios that significantly influence the movement of modes are expected to serve as guidelines for improving the performance of freight transport. So it is important to know what are the important variables and or on the range of how the variables / attributes change can affect modal shift.

Based on the formulation of the problem, the research aims to produce model of mode choice and provide input for the policy improvement and or improvement of freight transportation services based on the model estimation. To achieve this goal, the research objectives are formulated as follows:

1. Obtain data of transportation characteristics of goods as well as existing variables that influence the choice of modes with the survey revealed preference (RP).

2. Knowing what are the important variables that influence the choice of modes through mode choice model analysis based stated preference (SP) data.

3. Generate recommendations for policy makers to increase the attractiveness of freight transport mode.

\section{Contributions}

Freight transportation is a key supply chain component to ensure the efficient movement and timely availability of raw materials and finished products. Demand for freight transportation results from producers and consumers who are geographically apart from each other. Following trade globalization, the conventional road mode is no longer an all-time feasible solution, necessitating other means of transportation (and their combinations) [5]. Freight transportation has recently become a significant element in issues involving energy conservation, air pollution, foreign trade, inflation, economic growth and regional development [6]. Freight transportation has also become an important issue in logistics and supply chain management, due to the increasing concern about congestion, environmental impacts and safety. Due to market globalisation, the demand for more reliable, flexible, cost-effective, timely and visible door-to-door freight services has increased [7].

It is widely accepted that non-road freight transport is less energy intensive than freight transport by road. The use of other transport modes than truck for long haul freight transport can therefore contribute to more energy efficient transportation systems. As a result, the successful promotion of intermodal transport, using rail or sea on the long haul part, has been identified as the most critical action to achieve a sustainable transport sector [8].

However, despite these concerns, shippers and logistics providers cannot easily change their transport mode choice because they feel constrained by the logistics trade-offs, such as the trade-off between the levels of transport cost and time. The government or other service providers need to implement appropriate policies in such a way that service users are interested in changing transport mode choice. Therefore, efforts to improve the services of sea and railway modes are necessary to enhance the competitiveness of both modes.

The research related to mode choice analysis is an important step to formulate policies related to increasing the competitiveness of both modes. The expected result of analysis is important variables influence the freight mode choice and what scenarios need to be done related to those variables, so that users will be interested in switching modes. Mode choice is one of the most critical parts of any freight demand modelling framework [9]. The factors that influence mode choice need to be wellknown in terms of infrastructure, service quality, modal characteristics, logistics system characteristics, commodity characteristics, and so on. And the extent to which users are willing to change their transport mode choice in the event of any change in these factors.

The first stage of the study was to conduct a survey revealed preference (RP). One important stage before the RP survey is to conduct a preliminary survey. This stage aims to make observations of subjects and research objects so that the next step of the research becomes more focused. In addition, preliminary survey is useful to establish initial communication and dissemination of research activities to prospective respondents. This stage also aims to determine the important trends related to the choice of forwarder mode for shipment of goods and test the participation rate of prospective respondents. A survey of a small proportion of the population is also useful for assessing the credibility of data instruments and identifying potential errors in data instruments and recording data, observing respondent responses, and determining non-conformities in survey management before the actual survey

This paper aims to present the results of the analysis of preliminary survey descriptions among selected respondents in Surabaya. The respondents in question are the associates of the forwarder association. As association managers, it is expected that they have the experience and willingness to participate so that the initial survey results are expected to be credible enough to be useful inputs in the shipment of goods as the basis for the implementation of the RP survey.

\section{METHOD}

\section{A. Initial Variables Research}

Based on the results of the literature study, there are four most important factors influencing the decision of mode choice are: (1) cost [10] [11] [12] [13]; (2) time [14] [15]; (3) reliability [16] [17], and (4) service frequency [11] [14]. While the most commonly used attributes are: time, frequency, reliability, and flexibility. 
Therefore, the variables to be used will be closely related to the above findings.

The dependent variable in this research is the probability of choosing an alternative mode which is the function of the difference of utility of each mode. While the modal utility is a function of the difference in the value of the mode attribute. Option format is discrete (discrete choice), that is choosing one mode from some mode choice. Based on the literature study, a preliminary questionnaire format was prepared which contained question items regarding the important variables that influenced the choice of the current mode.

\section{B. Model Specifications}

Discrete choice models have been widely used to study individuals' behaviour in the mode choice context. Their theoretical underpinnings are found in the theory of rational choice and in the utility maximisation behavioural rule. Thus, the utility of alternative $\mathrm{j}$ to the decision maker $\mathrm{n}$ is represented by the random variable $\mathrm{U}_{\mathrm{jn}}=\mathrm{V}_{\mathrm{jn}}+\varepsilon_{\mathrm{jn}}$; where $\mathrm{V}_{\mathrm{jn}}$ is the deterministic or observable utility and $\varepsilon_{\mathrm{jn}}$ is a random term representing the portion of utility unknown to the analyst. Therefore, under the assumption of utility maximisation, it is only possible to model the choice probability of the different alternatives. Different assumptions about the distribution of the unobserved portion of utility $\varepsilon_{\text {jn }}$ result in different representations of the choice model. Thus, the widely used Multinomial Logit (MNL) and Nested Logit (NL) models are obtained when $\varepsilon_{\text {jn }}$ are independent and identically distributed (IID) extreme value and a type of generalised extreme value [18].

Currently mobilization of cargo from Surabaya to Jakarta and vice versa served by 3 modes of transportation, namely: road / truck, railway / train, and sea / ship [2]. As for export purposes, most exporters and forwarders in Java Island prefer container trucks for the shipment of exported goods through three major ports (Tanjung Priok, Tanjung Perak and Tanjung Emas). Therefore the types of modes considered in this dissertation are: trucks, trains, and ships. In this study will be compared two types of model specifications: Multinomial Logit (MNL) and Binomial Nested Logit (NL) [19]. As shown in Figure 1 and Figure 2 below.

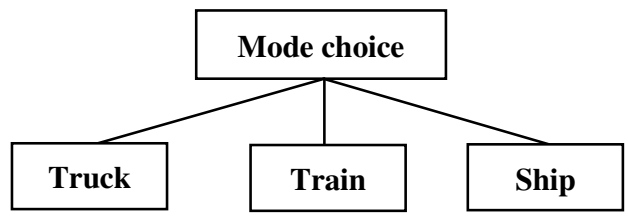

Figure 1. Multinomial Logit Model of Mode Choice in Surabaya-Jakarta Corridor

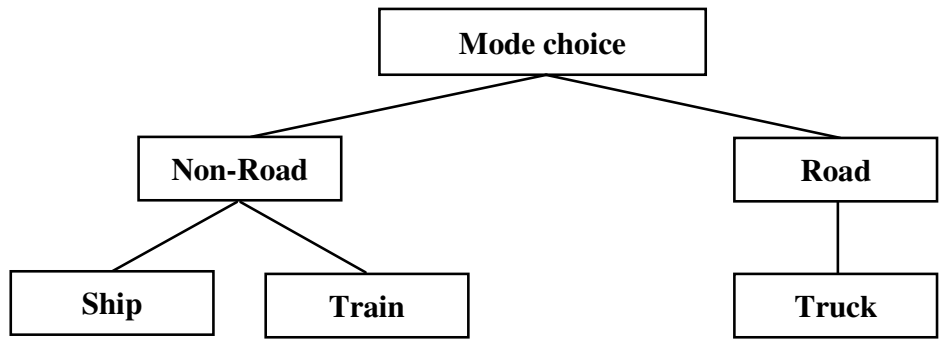

Figure 2. Binomial Nested Logit (NL) Model of Mode Choice in Surabaya-Jakarta Corridor

\section{Population and Sample}

Basically, the parties involved in mode choice decision making divided into two groups, namely: the shippers (shipper, intermediaries / forwarders) and receivers. However, freight forwarders as intermediary agents between shippers and carrier operators typically also behave like shippers [20]. Development of information technologies over the past 15-20 years has provided a high level of informatization and virtualization of technological processes at contemporary transport markets. This led to the changes in a role of freight forwarders as of companies providing intermediary services. Contemporary forwarders are the architects of supply chains that provide the most efficient way of interaction between the transport market participants. Therefore, the efficiency of the forwarding companies technological processes nowadays is one of the key factors which determines an efficiency of freight transport systems [21].

Therefore, the research population is a company engaged in the shipment of goods namely forwarders.
Data obtained from Indonesian Logistics and Forwarders Association (ILFA). While freight forwarder companies are planned to be the respondents those are domiciled in two cities: Surabaya and Jakarta. The data show a total of nearly 2,000 companies listed as ILFA members domiciled in Surabaya (356) and Jakarta (1,640) [22].

The minimum sample size based on [23] is 30 respondents per segment. In this research, the minimum sample for RP survey is planned to be 30 respondents respectively for companies domiciled in Jakarta and Surabaya, to get a total of 60 respondents. While the respondents in this preliminary survey are the board of the Association of Logistics and Forwarders of Indonesia (ALFI) Regional Executive Board (DPW) of East Java Province.

\section{Data Collection and Data Analysis}

Surveys in the field of transportation often use two approaches, namely : revealed preference (RP) and stated preference (SP). The main difference between the two 
approaches is that RP typically corresponds to actual choice and or behavior in a real transport environment, while SP data is associated with choice and or travel behavior in a hypothetical environment. However, RP data may complement SP data in terms of SP data references, SP data calibration, or combined data analysis of RP and SP. Each approach has its advantages and disadvantages [24].

A relatively new approach in preference surveys is the use of internet and or the web. Compared to other survey modes, internet surveys have competitive advantages in terms of speed and costs. It also allows for a more efficient way of dealing with respondents. As other computer-based methods, surveys on internet derive advantage from skip patterns, randomisation of questions and customized design. Customized design is crucial in SP analyses; it makes the attribute levels more familiar to respondents and provides higher variation in the observations. However, there is a potential disadvantage of using self-administered internet surveying, the lack of access to the internet in certain groups of the population which may yield survey mode biases in SP parameter estimates [25].

In this case, the types of RP data to be collected are: firm characteristics, commodity characteristics, mode characteristics, travel characteristics, and qualitative data: the reason for selecting the current mode. The method that will be used is focus group discussion. Analysis of RP data using descriptive statistics. The results of the analysis are useful for SP survey data guidance in terms of : the choice of selected attributes and their level, the preparation of the experimental design, and the SP data questionnaire. This stage also aims to minimize the occurrence of bias and or outlier. One important stage before the RP survey is to conduct a preliminary survey. This stage aims to make observations of subjects and research objects so that the next step of the research becomes more focused. This preliminary data analysis is planned to only consider one commodity, namely the commodity most often served by the respondent company.

Analysis of RP data uses descriptive statistics, especially in the form of tables and graphs. The result of $\mathrm{RP}$ data analysis is useful to be a survey guide of SP data in terms of: selected attributes / variables and levels, preparation of experimental designs, and SP data questionnaires. This stage is also the first filter to minimize the occurrence of bias and or outlier. Analysis of SP data will be grouped into two main models, namely: multinomial logit (MNL) and binomial nested logit (NL). Data analysis will be grouped according to the type of forwarder company shipping commodity. It aims to determine the differences in the tendency of mode choice and user response over the attributes that exist based on the characteristics of their shipping commodities and to know how the importance of attributes by type of commodity.

\section{RESULTS AND DISCUSSION}

Preliminary surveys are conducted prior to the implementation of RP survey using focus group method. Data collection was conducted by sending questionnaires to the respondents. At this stage, it is also offered to selected respondents whether willing to follow the next survey stages: focus groups and internet-based surveys. Delivery and return of questionnaires are coordinated at ALFI office of East Java Province. The structure of the preliminary survey questionnaire consists of:

1. Respondents' private and company data queries

2. Inquiries about shipping data (commodity type, shipment frequency, shipment unit, shipment size, and shipment value)

3. Inquiries about travel data (origin-destination, average length of travel, shipping costs, delays, damages, routes within Java, transit (location, duration, cost)

4. Questions about the existing mode (type of land mode, mode of origin-destination, reason for mode choice, essential attributes of modes, obstacles in modal shift)

5. Request suggestion for improvement of questionnaire Distribution of questionnaires to respondents was conducted in mid-February 2016. Return of questionnaires almost two weeks after dispersal. From 11 members of the board of association only 8 respondents who returned the preliminary questionnaire. Results and discussion descriptively grouped as follows:

\section{A. Shipment Data}

Based on the results of the preliminary survey, answers obtained form respondents on the number of commodities and types of commodity as shown in Table 1 and Table 2. A total of 8 companies serving the shipment of 19 commodities (Table 1), which is divided into 10 types of commodities (Table 2). It appears that one company could serve the shipment of some commodities. Most of the commodities are plantation products $(21 \%)$. In subsequent answers, the respondents did not follow the filling instructions to answer based on each type of shipping commodity. Therefore, the questionnaire needs tob added with clear information to answer questions per commodity and/or make a format with detailed questions per commodity.

Respondents' answers to the frequency of shipment questions as shown in Table 3, respondents answered globally the number of deliveries for a month for all commodities. More detailed answers include the shipment frequency per commodity type and each container size used and the value of each shipment not being answered as expected. This could happen because of an unclear question format, respondent's aversion, or a combination of both. Therefore, for the next stage survey, the questionnaire will be detailed according to the type of each commodity served by the forwarder company and conducted face-to-face interviews. The results also show that all types of commodities use various sizes of containers for cargo shipment. This needs to be considered to focus the research on container based cargo. 
Table 1. Number of comodities

\begin{tabular}{ccc}
\hline No & Company name & Number of commodities \\
\hline 1 & PT Bintang Samudra Pratama & 3 \\
2 & PT Trans Pasific Atlantic & 4 \\
3 & PT TKS & 1 \\
4 & PT Dirgantara Surya Persada & 5 \\
5 & PT Zenith Zone Logistic & 1 \\
6 & PT Intrajaya Giri Kencana & 3 \\
7 & PT Suboka Putra Nusantara & 1 \\
8 & PT Puma Logistik Indonesia & 1 \\
\hline & Total & 19 \\
\hline
\end{tabular}

Table 2. Type of commodities

\begin{tabular}{cccc}
\hline No & Type of commodity & Total & Percentage $(\%)$ \\
\hline 1 & Agricultural & 2 & 10.5 \\
2 & Plantation & 4 & 21 \\
3 & Seafood & 1 & 5.3 \\
4 & Pulp & 4 & 21 \\
5 & Machinery & 1 & 5.3 \\
6 & Electronics & 1 & 5.3 \\
7 & Food & 1 & 5.3 \\
8 & Fertilizer & 1 & 5.3 \\
9 & Animal feed & 2 & 10.5 \\
10 & Metal material & 2 & 10.5 \\
\hline \multicolumn{2}{r}{ Total } & 19 & 100 \\
\hline
\end{tabular}

Table 3. Total shipment of all commodities

\begin{tabular}{ccc}
\hline No & Company name & Container per month \\
\hline 1 & PT Bintang Samudra Pratama & 200 \\
2 & PT Trans Pasific Atlantic & 75 \\
3 & PT TKS & 20 \\
4 & PT Dirgantara Surya Persada & $80-100$ \\
5 & PT Zenith Zone Logistic & 70 \\
6 & PT Intrajaya Giri Kencana & 100 \\
7 & PT Suboka Putra Nusantara & 40 \\
8 & PT Puma Logistik Indonesia & n.a \\
\hline
\end{tabular}

\section{B. Travel Data}

The grouping of origin city of shipment into Surabaya and not Surabaya aims to know its relevance to the corridor Surabaya-Jakarta. Seen in Table 4, that shipments from Surabaya are only about half of shipments originating outside of Surabaya. However this may not necessarily indicate that the corridor with origin of shipment from Surabaya is irrelevant. In the next survey stage this finding should be related to the volume of cargo. Because it could be the volume of cargo coming from Surabaya is greater than outside Surabaya. Meanwhile, based on purpose of shipment (Table 5), $74 \%$ of total shipment is domestic shipments.

Table 6 shows the respondent's answer to the question of the average of shipment time, including the delay and the length of the transit (if any), from the origin to the destination of the shipment of the goods. However, the lack of this questionnaire is : questions about the delivery process from origin to destination along with sequence of transit are not stated clearly. Therefore, information on the length of transit time and the delay of the length of the total trip should be asked at the next survey stage. In addition, the question of the stages of the process of delivering goods from origin to destination needs to be detailed. This is required for the preparation of the service attribute level in the survey stated preference (SP).

Route within the island of Java used by forwarders to deliver cargo is presented in Table 7. It is shown that $58 \%$ of shipment used the southern route of Java Island, while the rest used the northern route of Java Island (Table 7). The results need to be carefully considered regarding the relevance of the research corridor. As well as the result in Table 4, in the next survey stage this finding should be related to the volume of cargo.

Table 4. Origin city of shipment

\begin{tabular}{cccc}
\hline No & City & Total & Percentage $(\%)$ \\
\hline 1 & Surabaya & 6 & 32 \\
2 & Non Surabaya & 13 & 68 \\
\hline Total & 19 & 100 \\
\hline
\end{tabular}


Table 5. Purpose of shipment

\begin{tabular}{cccc}
\hline No & Purpose & Total & Percentage (\%) \\
\hline 1 & Domestic & 14 & 74 \\
2 & Export & 5 & 26 \\
\hline & Total & 19 & 100 \\
\hline
\end{tabular}

Table 6. Average shipment time

\begin{tabular}{ccc}
\hline No & Company name & Shipment time \\
\hline 1 & PT Bintang Samudra Pratama & $4-5 \mathrm{hr}$ \\
2 & PT Trans Pasific Atlantic & $21 \mathrm{day}$ \\
3 & PT TKS & $3 \mathrm{hr}$ \\
4 & PT Dirgantara Surya Persada & $2-3 \mathrm{hr}$ \\
5 & PT Zenith Zone Logistic & $8 \mathrm{day}$ \\
6 & PT Intrajaya Giri Kencana & $20-40$ day \\
7 & PT Suboka Putra Nusantara & $1-2$ day \\
8 & PT Puma Logistik Indonesia & 30 day \\
\hline
\end{tabular}

Table 7. Route within the island of Java

\section{Existing Mode}

Respondents' answers on the types of land modes used within the island of Java are : $84 \%$ using container truck and $16 \%$ using a combination of truck-train (Table 8). These results indicate that use of train is likely to be combined with truck for door to door service. It is also found that the non-land modes used are: aircraft as much as 3 types of commodity and ship/vessels 16 types of commodity (Table 9).

The results of respondents' answers to questions about the main factors/attributes and reasons of the existing mode choice (Table 10 and Table 11) show that the

\begin{tabular}{cc} 
Total & Percentage $(\%)$ \\
\hline 8 & 42
\end{tabular}

$11 \quad 58$

$19 \quad 100$

answer matches the findings in the literature study, i.e the reason for cost is the main reason. While the next reason is the safety/loss/damage and travel time. This is consistent answer in Table 12, that the main reason for inhibiting to switch mode is the cost reason.

In addition to the above respondents' answers, some important suggestions from the respondents are : the need for more detailed questions related to the choice of modes due to the complexity of the logistics system, some questions that are biased and multiple interpretations need to be minimized.

Table 8. Type of land mode

\begin{tabular}{cccc}
\hline No & Land mode & Total & Percentage (\%) \\
\hline 1 & Container truck & 16 & 84 \\
2 & Train & 0 & 0 \\
3 & Combination of truck-train & 3 & 16 \\
\hline & Total & 19 & 100 \\
\hline
\end{tabular}

Tabel 9. Type of non land mode

\begin{tabular}{cccc}
\hline No & Mode & Total & Percentage $(\%)$ \\
\hline 1 & Aircraft & 3 & 16 \\
2 & Ship & 16 & 84 \\
\hline & Total & 19 & 100 \\
\hline
\end{tabular}

Table 10. Most important attribute of existing mode

\begin{tabular}{ccc}
\hline No & Company name & Attribute \\
\hline 1 & PT Bintang Samudra Pratama & Cost \\
2 & PT Trans Pasific Atlantic & Loss/damage \\
3 & PT TKS & Realibility \\
4 & PT Dirgantara Surya Persada & Cost \\
5 & PT Zenith Zone Logistic & Cost \\
6 & PT Intrajaya Giri Kencana & Loss/damage \\
7 & PT Suboka Putra Nusantara & Cost \\
8 & PT Puma Logistik Indonesia & Cost \\
\hline
\end{tabular}


Table 11. Reasons of existing mode choice

\begin{tabular}{ccc}
\hline No & Company name & Reasons \\
\hline 1 & PT Bintang Samudra Pratama & Characteristic of commodity, route, safety/loss/damage, reliability \\
2 & PT Trans Pasific Atlantic & Characteristic of commodity, origin-destination of shipment \\
3 & PT TKS & Travel distance, route \\
4 & PT Dirgantara Surya Persada & Origin-destination of shipment \\
5 & PT Zenith Zone Logistic & Speed, route, owner/shipper's demand \\
6 & PT Intrajaya Giri Kencana & Cost, safety \\
7 & PT Suboka Putra Nusantara & Safety, speed \\
8 & PT Puma Logistik Indonesia & Safety, speed \\
\hline
\end{tabular}

Table 12. Inhibiting factors to switch mode

\begin{tabular}{ccc}
\hline No & Company name & Inhibiting factors \\
\hline 1 & PT Bintang Samudra Pratama & Reliability, cost, service continuity \\
2 & PT Trans Pasific Atlantic & Cost and service of transhipment \\
3 & PT TKS & Reliability \\
4 & PT Dirgantara Surya Persada & Cost \\
5 & PT Zenith Zone Logistic & n.a \\
6 & PT Intrajaya Giri Kencana & n.a \\
7 & PT Suboka Putra Nusantara & Cost \\
8 & PT Puma Logistik Indonesia & Familiarity \\
\hline
\end{tabular}

\section{CONCLUSION}

Important conclusions for follow-up of the revealed preference (RP) survey using focus group are:

1. The return rate of the questionnaire / response rate is relatively low because with 11 respondents it turns out that only 8 respondents are willing to return and answer the questionnaire. This indicates that the questionnaire method is not effective so it needs to be combined with other methods, such as: face to face interview and or focus group.

2. Implementation of the next survey, the survey revealed preference (RP), needs to consider that each company has more than one shipping commodity so it is necessary to classify the questions of the characteristics of mode choice and travel based on the characteristics of each commodity

3. The use of dominant containers in the shipment of goods. Therefore, research is relevant if it focuses on container based freight transport. This is also relevant to the competition of all three modes: container trucks, container trains, and ships.

4. Preliminary survey results indicate that the main reasons for selecting the existing mode are consecutive: shipping costs, loss/damage, and time travel

5. The RP survey object needs to be expanded also among operators e.g. ports in Surabaya and Jakarta for other important relevant data, e.g. transportation rates, types of services at ports, port capacity, etc.

The results of this preliminary survey are expected to formulate the initial findings as a basis for the preparation of RP experimental design with focus groups and SP methods and further for the preparation of webbased SP surveys. One of the weaknesses of internet and / or web based surveys is the lack of personal approaches with respondents and the "dishonesty" of respondents in answering. Therefore, combining methods: RP (with focus groups) and SP (with face-to-face interviews and internet surveys), are expected to minimize the weaknesses of each method.

\section{AKNOWLEDGEMENTs}

The authors would like to thank the board of the Indonesian Logistics and Forwarders Association (ALFI) of the East Java Province Executive Board for their cooperation that has been willing to take the time to fill out the questionnaire in the preliminary survey

\section{REFERENCES}

[1] T. M. Simatupang, "The Problem of Goods Transportation in Indonesia," in Seminar on Building Road Mode for Multimodal Transportation System and Effective and Efficient Logistic in Facing the ASEAN Economic Community (MEA), 2015.

[2] A. E. Prasetyo and F. Hadi, "Analysis of freight transport of freight on Java island road (case study: corridor Surabaya - Jakarta)," J. Tek. POMITS, vol. 2, no. 1, 2013.

[3] K. Arunotayanun and J. W. Polak, "Taste heterogeneity and market segmentation in freight shippers' mode choice behaviour," Logist. Transp. Rev., vol. 47, no. 2, pp. 138-148, 2011.

[4] M. T. Nugroho, A. E. Whiteing, and G. de Jong, "Port and inland mode choice from the exporters' and forwarders' perspective," in UNSPECIFIED WCTRS SIG2 2015 Confererence, 2015.

[5] M. S. Seifi, N. P. Dellaert, W. Nuijten, T. Van Woensel, and R. Raoufi, "Multimodal freight transportation planning: A literature review," Eur. J. Oper. Res., vol. 233, pp. 1-15, 2014.

[6] S. Kofteci, M. Ergun, and H. S. Ay, "Modelling freight transportation preferences : Conjoint analysis for Turkish Region,' Sci. Res. Essays, vol. 5, pp. 2016-2021, 2010.

[7] H.C. Kim, A. Nicholson, and D. Kusumastuti, "Analysing freight shippers' mode choice preference heterogeneity using latent class modelling", Transportation Research Procedia, vol. 25C, pp. 1109 1125

[8] T.A. Mathisen and T. E. S. Hanssen, "The academic literature on intermodal freight transportation", Transportation Research Procedia, vol. 3, pp. 611-620, 2014.

[9] Samimi, K. Kawamura, and A. Mohammadian, "A behavioral analysis of freight mode choice decisions", Transportation Planning and Technology, vol. 34, no. 8, pp. 85-869, December 2011.

[10] M. Ravibabu, "A nested logit model of mode choice for inland movement for export shipments : A case study of containerised export cargo from India", Research on Transportation Economics, vol. 38, pp. 91-100, June 2012. 
[11]M.R. Brooks, S.M Puckett, D.A. Hensher, and A. Sammons, "Understanding mode choice decisions: A study of Australian freight shippers", Journal of Maritime Economic \& Logistic, vol. 14, pp. 274-299, 2012

[12]M. Gursoy, "A decision supportive method for multimodal freight transport mode choice: An example from Turkey", Iranian Journal of Science and Technology, vol. 34, no. B4, pp. 461-470, 2010

[13] S. Kofteci, "Trade-off analysis based freight mode choice model : A case study of Turkey", International Journal of Natural and Engineering Science, vol. 3, no. 3, pp. 37-42, 2010.

[14]L.S. Barus, S.P. Hadiwardoyo, H.M. Flores, and J.S. Batoz, "Modal competition for freight in land transportation on JakartaSurabaya corridor", Civil and Environmental Research, vol. 3, no. 11 , pp. 67-75, 2013.

[15] Y. Wang, C. Ding, C. Liu, and B. Xie, " An analysis of interstate freight mode choice between truck and rail: A case study of Maryland, United States", Procedia-Social and Behavioral Sciences, vol. 96, pp. 1239-1249, 2013

[16] T.P. Moschovou and G.A. Giannopoulos, "Modeling freight mode choice in Greece", Procedia-Social and Behavioral Sciences, vol. 48, pp. 597-611, 2012.

[17]M. Feo, R. Espino, and L. Garcia, "A stated preference analysis of Spanish freight forwarders modal choice on the South-West Europe motorway of the sea", Transport Policy, Vol. 18, pp. 60-67, June 2010.

[18] A.I. Arencibia, M.F. Valero, and L.G. Menendez, "Modelling mode choice for freight transport using advanced choice experiments", Transportation Research Part A, vol. 77, pp. 252 267,2015

[19]F.S. Koppelman and C.Bhat, "A self instructing course in mode choice modelling : multinomial and nested logit models", U.S Department of Transportation, 2006.

[20] V. Reis, "Analysis of mode choice variables in short-distance intermodal freight transport using an agent-based model", Transportation Research Part A, vol. 61, pp. 100-120, January 2014.

[21]V. Naumov and O. Kholeva, "Studying demand for freight forwarding services in Ukraine on the base of logistic portals data", Procedia Engineering, vol. 187, pp. 317-323, 2017.

[22] Indonesian Logistics and Forwarders Association, "Business Directory and Members Profile ALFI/ILFA", Jakarta, 2013.

[23] Pearmain, J. Swanson, E. Kroes, and M. Bradley, , "Stated Preference Techniques : A Guide to Practice", 2nd Edition, Steer Davies Gleave \& Hague Consulting Group, UK 1991, pp. 60-61

[24] J.J. Louviere, D.A. Hensher, and J.D. Swait, "Stated Choice Methods Analysis and Applications", Cambridge University Press, UK, 2000, pp. 228-231

[25] ̊̊. Nossum and K. Veisten, , "Collecting data by internet on stated preference for transport supply: three case studies on survey mode comparison", Transport and Telecommunication, vol. 12, no 1, pp. 16-24, 2011. 